\title{
ХРОНІЧНИЙ ГАСТРИТ: СУЧАСНІ КЛІНІКО-МОРФОЛОГІЧНІ УЯВЛЕННЯ (ЛЕКЦІЯ)
}

Державна наукова установа "Науково-практичний центр профілактичної та клінічної медицини" Державного управління справами, м. Київ, Україна

\section{Резюме}

У лекції наведено сучасні клініко-морфологічні класифікації хронічного гастриту. Виділено основний етіологічний чинник хронічного гастриту - інфекцію Н. pylori. Аано визначення поняття атрофії, відзначено, що атрофія може бути імітованою за рахунок запального інфільтрату. Розглянуто типи атрофії - метапластичний і неметапластичний. Зазаначено, що метаплазія слизової оболонки шлунка буває двох типів - повного (тонкокишкова) та неповного (товстокишкова); підкреслено, що неповна метаплазія є передраковим станом. Аано характеристику дисплазій слизової оболонки шлунка. Розглянуто два шляхи канцерогенезу раку шлунка та відзначено, що Н. pylori належить до канцерогенів I групи. Коротко розглянуто інші нехелікобактерні форми хронічного гастриту.

Ключові слова: хронічний гастрит, інфекція Н. pylori, атрофія, метаплазія, дисплазія.

Однією з актуальних проблем сучасної гастроентерології є хронічний гастрит (ХГ) - найоширеніше органічне захворювання шлунка. Вважається, що від $50 \%$ до $80 \%$ дорослого населення страждають від ХГ. Проте вірогідність оцінки поширеності захворювання обмежено об'єктивними труднощами його діагностики. 3 одного боку, ХГ тривалий час може не мати клінічних симптомів, що дають привід для звернення до лікаря, а з іншого - верифікація діагнозу можлива лише на підставі морфологічного дослідження.

Наразі вважається, що «хронічний гастрит» $€$ поняттям морфологічним, і про наявність хронічного запалення мова може йти лише на підставі результатів морфологічного дослідження. Тобто, діагноз «хронічний гастрит» передбачає обов'язкове морфологічне підтвердження.

Отже, клініцист перед проведенням біопсії слизової оболонки шлунка й отримання патоморфологічного висновку не вправі виставляти діагноз «хронічний гастрит». Зазвичай на попередньому етапі використовується визначення «невиразкова диспепсія». Цей термін відображає наявність у хворого певних симптомів, що виникають внаслідок пору- шень насамперед шлункової секреції та гастродуоденальної моторики.

Широке використання морфологічних методів діагностики є надзвичайно важливим у сучасній гастроентерології. Морфологічне дослідження біопсійного матеріалу не лише має безпосереднє діагностичне значення, а й дозволяє судити про динаміку захворювання, певною мірою визначати прогноз, тактику лікування, а також оцінювати його результати.

ХГ вважається передраковим станом, тобто захворюванням, що обумовлює підвищений ризик виникнення раку. В слизовій оболонці шлунка (СОШ) за ХГ розвиваються передпухлинні зміни морфологічні зміни тканин, в яких імовірність виникнення раку є більшою, ніж ву нормальних тканинах.

ХГ - поліетіологічне захворювання, в розвитку якого беруть участь екзо- й ендогенні чинники нераціональне (як у кількісному, так і в якісному розумінні) харчування, порушення його режиму, збільшення психоемоційного навантаження, стреси, спадково-конституціональні особливості. Але 
насамперед розвиток хронічного гастриту пов'язано 3 інфекцією Helicobacter pylori та автоімунними процесами.

За результатами проспективного десятирічного дослідження встановлено, що у пацієнтів, інфікованих Н. pylori, хронічний атрофічний гастрит розвивається у $40 \%$ випадків і не розвивається в жодному випадку за відсутності хелікобактерної інфекції. Інфікування $\mathrm{H}$. pylori відбувається переважно в дитинстві, серед дорослого населення щорічно інфікуються лише 0,3-0,5\%. Причому спочатку виникає гостра інфекція шлунка, що на сьогоднішній день є доведеним фактом. Запальна реакція слизової шлунка проявляється у вигляді нейтрофільного гастриту з транзиторною гіпохлоргідрією, що зберігаються приблизно впродовж 4 місяців без застосування ерадикаційної терапії. Потім запалення переходить у хронічну стадію та триває протягом багатьох років.

Термін “хронічний гастрит” у буквальному перекладі означає хронічне запалення всієї стінки шлунка, натомість клініко-морфологічно мова йде лише про слизову оболонку, де поряд із запальними та дистрофічними процесами порушується клітинне оновлення, що є не менш важливою ознакою ХГ.

До основних морфологічних ознак ХГ належать запалення, атрофія та порушення клітинного оновлення, в тому числі метаплазія та дисплазія. Саме дисрегенерація визначає морфогенез, клініко-морфологічну картину та прогноз ХГ

\section{КЛАСИФІКАЦІЯ ХРОНІЧНОГО ГАСТРИТУ}

Вважається, що класифікація ХГ має давати підстави для визначення тактики лікування та прогнозу захворювання. Запропонована 1973 року класифікація виділяла три основних форми гастриту:

- гастрит типу А (автоімунний), що характеризується переважним ураженням тіла шлунка;

- гастрит типу В, що розвивається внаслідок інфікування СОШ бактерією Helicobacter pylori та запаленням переважно антрального відділу шлунка;

- $\quad$ гастрит типу C (хіміко-токсичний), який розвивається внаслідок закидання жовчі в шлунок із дванадцятипалої кишки, так званого дуоденогастрального рефлюксу, або впливу на СОШ деяких лікарських засобів, у першу чергу нестероїдних протизапальних засобів (НПЗ3).

Сіднейську класифікацію було прийнято 1990 року. Згідно з цією класифікацією діагноз ХГ формується на підставі оцінки 4 ознак захворювання:
- локалізації патологічного процесу;

- гістологічних змін;

- макроскопічних змін СОШ, що виявляються в ході ендоскопії;

- етіологічних чинників.

Наразі більшість гастроентерологів користуються Сіднейською класифікацією Х'юстонського перегляду (1996). Ця класифікація враховує етіологію, топографію та морфологію слизової оболонки шлунка.

Топографія ХГ значною мірою визначає прогноз: антральний гастрит, що супроводжується гіперсекрецією хлористоводневої кислоти, провокує виникнення дуоденальної виразки (виразковий фенотип), а гастрит тіла шлунка - раку та виразки шлунка (раковий фенотип).

Морфологічна класифікація виділяє гастрит атрофічний і неатрофічний, а за типом запалення - активний (переважно нейтрофільна інфільтрація) та неактивний (переважає інфільтрація лімфоцитами).

Сіднейська класифікація пропонує за допомогою візуально-аналогової шкали оцінювати вираженість колонізації $H$. pylori, активність хронічного запалення, атрофію та метаплазію СОШ:

- колонізація H. Pylori - якщо Н. pylori знайдено щонайменше в одному з біоптатів, встановлюється діагноз "асоційований з Н. pylori хронічний гастрит”;

- інфільтрація нейтрофілами - основний показник активності;

- хронічне запалення - наявність навіть 1-2 плазматичних клітин ву полі зору свідчить про хронічне запалення;

- атрофія - в полі зору великого збільшення щонайбільше 2 поперечно зрізані залози (в нормі їх більше);

- кишкова метаплазія: 1) якісна оцінка: повна (тонкокишкова) та неповна (товстокишкова); 2) кількісна оцінка: ураження до 5\% слизової шлунка - метаплазія слабко виражена, до 20\% помірна, понад $20 \%$ - виражена.

Міжнародною групою з вивчення атрофії СОШ (Новий Орлеан) 2002 року запропоновано нову морфологічну класифікацію ХГ, в якій атрофію визначено як зменшення об'єму залоз, властивих даному відділу шлунка, та виникнення кишкової метаплазії. Також було введено поняття про невизначену атрофію СОШ - коли залоз у гістологічних препаратах мало через те, що їх заміщено запальним інфільтратом. Класифікація виділила дві основні форми атрофії СОШ - із метаплазією та без 
метаплазії. Проте більшість фахівців із цим не погоджуються, оскільки у гістологічному зрізі шматочку СОШ метаплазія може не визначатися не тому, що вона відсутня в СОШ, а тому, що вона не потрапила у шматочок біопсійного матеріалу.

Група вчених, до складу якої увійшли патоморфологи з більшості країн світу, 2005 року запропонувала Міжнародну класифікацію, що отримала назву OLGA (Operative Link for Gastritis Assessment). Ця класифікація оцінює ступінь і стадію ХГ. Ступінь визначається за вираженістю запальної інфільтрації, а стадія - за вираженістю атрофії. На відміну від Сіднейської класифікації, активність ХГ у новій класифікації не оцінюється, а ступінь ХГ визначається сумарною інфільтрацією строми СОШ нейтрофілами та лімфоцитами. За такого підходу втрачається інформація, яка є корисною для прийняття рішення щодо ерадикації.

Для морфологічної діагностики необхідно брати шматочки СОШ щонайменше з 5 зон шлунка: 3 з антрума - 3 великої та малої кривизни та з кута шлунка; 2 з тіла -- з великої та малої кривизни або з передньої та задньої стінки (рис. 1). Біопсія з тіла шлунка $є$ необхідною насамперед для контролю лікування: за неефективної антихелікобактерної терапії Н. pylori таi нейтрофіли зникають з антрума, але з'являються в тілі шлунка. Необхідність біопсії з кута шлунка визначається тим, що тут часто розвиваються передракові зміни.

Група OLGA 2008 року запропонувала візуально-аналогову шкалу для оцінки атрофії СОШ, за якою шляхом поетапних підрахунків кількості та відсотка атрофованих залоз у шматочку СОШ визначають ступінь атрофії ХГ (рис. 2). Ця шкала $є$ досить складною. Відомий патоморфолог професор Аруін Л.І. вважає, що ії тяжко буде використовувати в щоденній практиці

\section{ВІЗУАЛЬНО-АНАЛОГОВА ШКАЛА ОLGА (2008)}

1. У кожному з 5 біоптатів (3 з антруму та 2 з тіла шлунка) оцінюють по 10 правильно орієнтованих залоз.

2. Відзначають кількість атрофованих залоз $\times 10$ (\% атрофії СОШ).

3. Визначають середній відсоток атрофії для антруму та тіла - суму відсотків, поділену на кількість біоптатів.

4. Переводять відсотки в бали.

Російськими морфологами на III з'їзді патологоанатомів (Самара, 2009) було об'єднано принцип візуально-аналогової шкали модифікованої

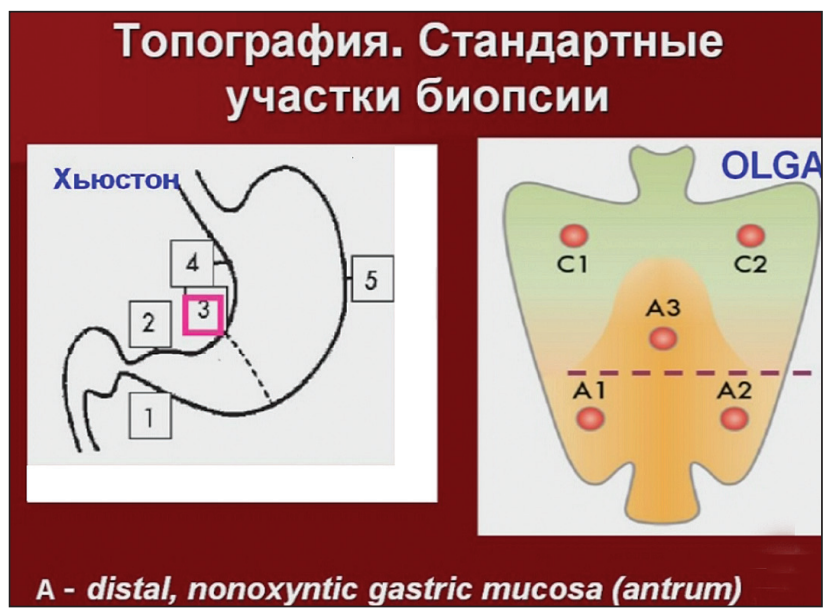

Рис. 1. Схема взяття шматочків слизової оболонки шлунка для гістологічного дослідження.

Сіднейської системи та табличної оцінки ступеня та стадії ХГ. Замість розрахунків запропоновано оцінювати по 2 біоптати з тіла і 3 з антрального відділу шлунка, складаючи в сумі картину гістологічних препаратів, подібно тому, як морфологи оцінюють ступінь градації пухлин без арифметичних обчислень.

Вивчаючи стадії хронічного гастриту, вчені дійшли висновку, що у хворих на рак шлунка переважають III-IV стадії атрофії СОШ, і не трапляються стадії 0 і I. Згідно із сучасною класифікацією OLGA, якщо за результатами біопсії виявлено IIIIV стадії ХГ, це свідчить про необхідність включення пацієнта в групу ризику раку шлунка.

Систему OLGIM (Operative Link on Gastric Intestinal Metaplasia Assessment) було запропоновано 2010 року для оцінки інтестинальної метаплазії, в якій метаплазія (власне метапластична атрофія) оцінюється за таким же принципом, як і атрофія в системі OLGA. Слід зазначити, що класифікація OLGIM лише доповнює класифікацію OLGA та не може використовуватися замість неї, адже класифікація OLGA враховує як справжню, так і метапластичну атрофію, а OLGIM - лише метапластичну атрофію.

Попри наявність кількох сучасних класифікацій ХГ Сіднейська система (X'юстонський перегляд) не втратила своєї актуальності тому, що вона пропонує оцінку активності запального процесу, що є надзвичайно важливим для призначення ерадикаційної терапії й оцінки іiі результатів.

3 нової міжнародної класифікації 2005 р. можна використовувати запропоновані неметапластичний і метапластичний типи атрофії СОШ, поняття про 


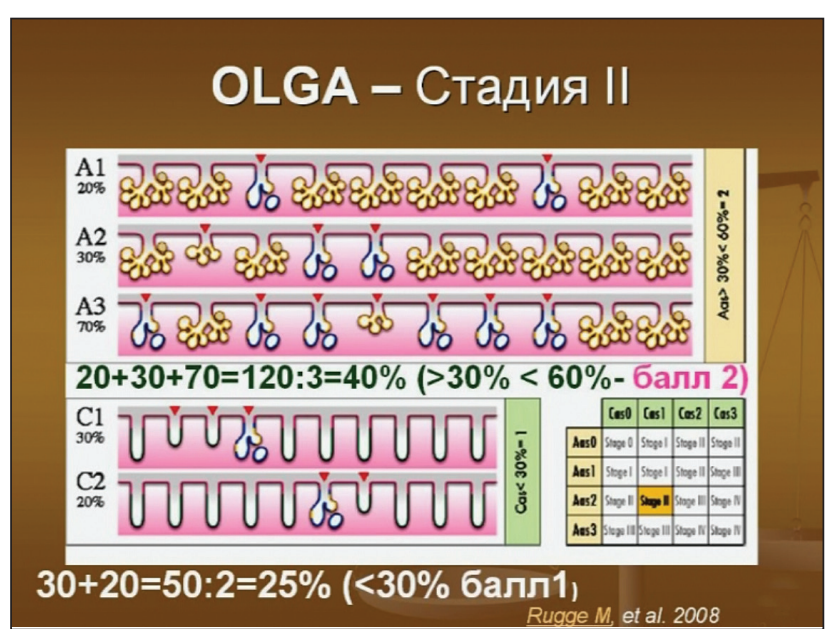

Рис. 2. Візуально-аналогова шкала системи OLGA-2008 для визначення стадії хронічного гастриту [10].

невизначену атрофію СОШ (якщо має місце кишкова метаплазія, про невизначеність атрофії СОШ мова йти не може). За даними більшості дослідників, у визначені кишкової метаплазії слід вважати, що має місце атрофія СОШ. Також у новій класифікації OLGA 2008 р. важливою є характеристика стадій ХГ. Встановлення стадії є необхідним для формування груп ризику раку шлунка, оцінки динаміки гастриту та результатів лікування.

Ми пропонуємо поєднання всіх трьох класифікацій із визначенням ступеня та стадії ХГ, із зазначенням ступеня запальної інфільтрації та відсотка атрофії, наявності атрофії справжньої або метапластичної (або їх поєднання), оцінки ступеня активності ХГ, визначення наявності Н. pylori (забарвленням за Романовським-Гімза, сріблом за Вартіном-Старрі, імуногістохімічним методом), із визначенням цих показників окремо для антрального відділу та тіла шлунка. Приклад патоморфологічного висновку:

1) У шматочку слизової з антрального відділу шлунка по малій кривизні - хронічний атрофічний гастрит 3 осередковою повною (тонкокишковою) метаплазією залоз (атрофія 30\%). 2) 3 кута шлунка - хронічний атрофічний гастрит 3 осередковою повною (тонкокишковою) та неповною (товстокишковою) метаплазією залоз (атрофія 30\%). 3) 3 антрального відділу по великій кривизні - хронічний атрофічний гастрит 3 осередковою повною (тонкокишковою) метаплазією залоз (атрофія 50\%). 4) 3 тіла шлунка по малій кривизні - хронічний атрофічний гастрит із повною (тонкокишковою) метаплазією залоз (атрофія 30\%). 5) 3 тіла шлунка по великій кривизні - хронічний поверхневий гастрит. Класифікація OLGA: антральний відділ ступінь I, стадія II. Тіло шлунка - ступінь I, стадія I. Знайдено бактерії Н. pylori в антральному відділі та тілі шлунка.

Отже, морфологічна діагностика ХГ є вирішальною у встановленні діагнозу та надзвичайно важливою у визначенні подальшої тактики ведення хворих. Використання сучасної та попередніх класифікацій ХГ у комплексі дозволяє досягти максимально інформативної діагностики основних його проявів, за якими визначаються тактика лікування та ефективність терапії.

На завершення розгляду класифікацій ХГ слід згадати Міжнародну класифікацію хвороб X перегляду (ВОО3), де визначено коди для різних форм гастриту:

К 29.3 Хронічний поверхневий гастрит

К 29.4 Хронічний атрофічний гастрит (атрофія шлунка)

К 29.5 Хронічний гастрит, не уточнений (антральний, фундальний)

\section{К 29.6 Інші гастрити}

Останнім часом оприлюднено (в електронному форматі) для обговорення Міжнародну класифікацію хвороб XI перегляду (ВОО3), яку планується представити на затвердження 2019 року, а ввести в дію з січня 2022 року. У цій класифікації виділено значно більше рубрик ХГ, ніж у попередній, їх більше деталізовано. Наводимо основні коди ХГ за Міжнародною класифікацією хвороб (MKX) XI перегляду:

DA 42.1 Helicobacter pylori індукований гастрит

DA 42.2 Еозинофільнийгастрит

DA 42.3 Лімфоцитарний гастрит

DA 42.4 Алергічнй гастрит

DA 42.5 Гастрит, пов'язаний

з дуоденогастральним рефлюксом

DA 42.7 Гастрит невиясненої етіології зі специфічними ендоскопічними або патологічними ознаками

DA 42.71 Хронічний поверхневий гастрит невиясненої етіології

DA 42.73 Хронічний атрофічний гастрит невиясненої етіології

DA 42.74 Метапластиний гастрит невиясненої етіології (інтестинальна метаплазія)

Слід також зазначити, що в MKX XI перегляду є коди щодо H. pylori:

XN3DY Helicobacter pylori.

(Коментарі щодо кодів у розділі «Захворювання травної системи» Міжнародної класифікації хвороб 
XI перегляду (BOO3) ми плануємо опублікувати у наступних номерах наукового журналу «Клінічна та профілактична медицина»).

\section{МОРФОЛОГІЧНІ ОЗНАКИ ХЕЛІКОБАКТЕРНОÏ ІНФЕКЦІ}

Клініцисту насамперед необхідно інформацію про наявність або відсутність бактерій Н. pylori у гастробіоптатах. Виявляють Н. pylori за допомогою забарвлення за Романовським-Гімза, сріблом за Вартіном-Старрі, а також імуногістохімічним методом.

Для оцінки ефективності лікування необхідними також є показники динаміки ступеня колонізації бактерій у різних відділах шлунка (рис.3). Для оцінки ступеня колонізації Н. pylori використовують шкалу Л.І. Аруіна: слабкий ступінь - до 20 бактерій в окремих полях зору; від 20 до 50 середній ступінь, понад 50 бактерій - високий ступінь колонізації.

Основні морфологічні ознаки хронічної хелікобактерної інфекції - осередкове пошкодження епітеліальних клітин і запальний інфільтрат у власній пластинці слизової оболонки. До складу інфільтрату СОШ за ХГ входять плазматичні клітини, лімфоцити, макрофаги, нейтрофіли та еозинофіли.

Основною ознакою запалення є інфільтрація власної пластинки слизової оболонки, переважно за рахунок плазматичних клітин. Більшість лімфоцитів, що інфільтрують власну пластинку Т-лімфоцити, переважно Т-хелпери, які забезпечують активацію інших імунокомпетентних клітин і синтез імуноглобулінів у відповідь на дію анти-

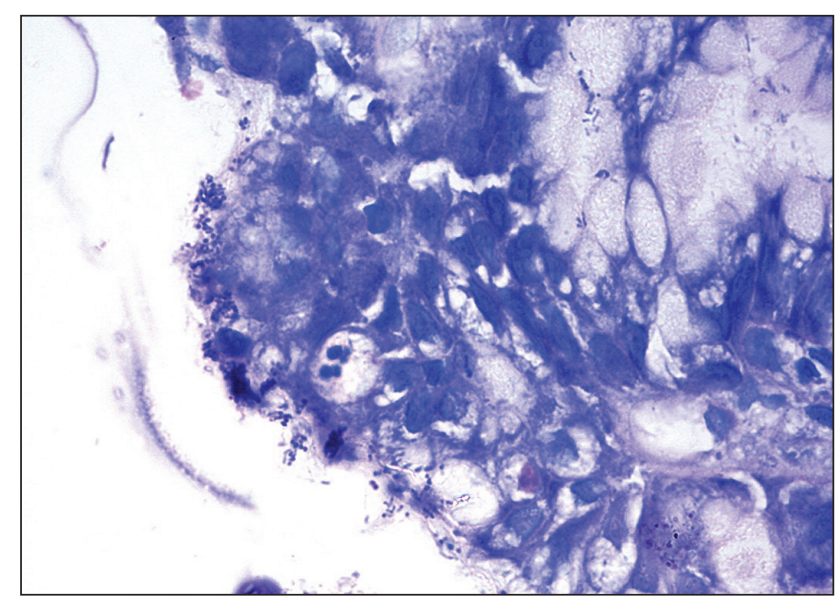

Рис. 3. Бактерії Н. pylori в епітелії та на поверхні епітелію слизової шлунка (середній ступінь колонізації).

Забарвлення за Романовським-Гімза. $\times 400$. генів. Під дією антигенів, що є продуктами H. pylori, у СОШ утворюється лімфоїдна тканина у вигляді лімфоїдних фолікулів, які спочатку мають невеликі розміри та складаються переважно 3 малих лімфоцитів, потім у лімфоїдних фолікулах у відповідь на антигенну стимуляцію з'являються реактивні центри; у процесі подальшої активації місцевої імунної системи реактивні центри можуть займати майже весь фолікул (рис. 4).

Наявність лімфоїдних фолікулів є специфічною морфологічною ознакою хронічної інфекції H. pylori; за даними більшості авторів вони відсутні в неінфікованих $H$. pylori пацієнтів.

\section{АКТИВНІСТЬ ХРОНІЧНОГО ГАСТРИТУ}

Активність запалення за ХГ визначається характером інфільтрату та ступенем його поширеності. За активного гастриту відбувається інфільтрація нейтрофілами епітелію та власної пластинки на тлі лімфо-плазмоцитарної інфільтрації, що є характерною для ХГ. Для 1-ї стадії хронічного активного гастриту характерною є помірна лейкоцитарна інфільтрація власної пластинки слизової оболонки, для 2-ї - більш виражена інфільтрація, яка, крім власної пластинки, поширюється і на епітелій - як поверхневий, так і ямковий (рис. 5). На 3-й стадії разом із вираженою інфільтрацією власної пластинки спостерігаються «внутрішньоямкові абсцеси», можуть утворюватись «абсцеси» в межах залози (рис. 6).

Хоча нова класифікація OLGA передбачає оцінку сумарної інфільтрації СОШ нейтрофілами та лімфоцитами, визначення ступеня інфільтрації нейтрофілами є надзвичайно важливим тому, що велика кількість останніх, що інфільтрує власну

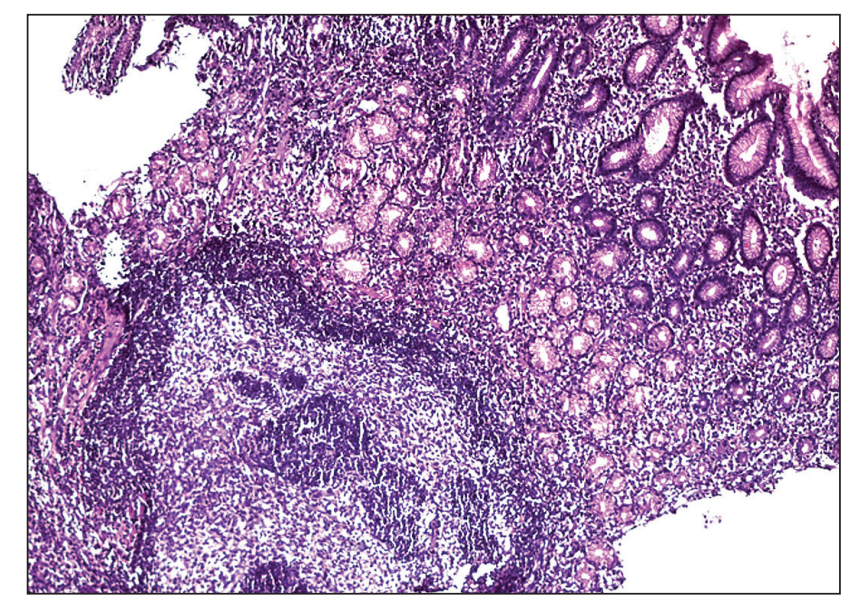

Рис. 4. Хронічний атрофічний гастрит із великим лімфоїдним фолікулом із реактивним центром, що займає значну частину фолікула. Забарвлення гематоксиліном-еозином, $\times 100$.

Клінічна та профілактична медицина, № 1(4)/2018 


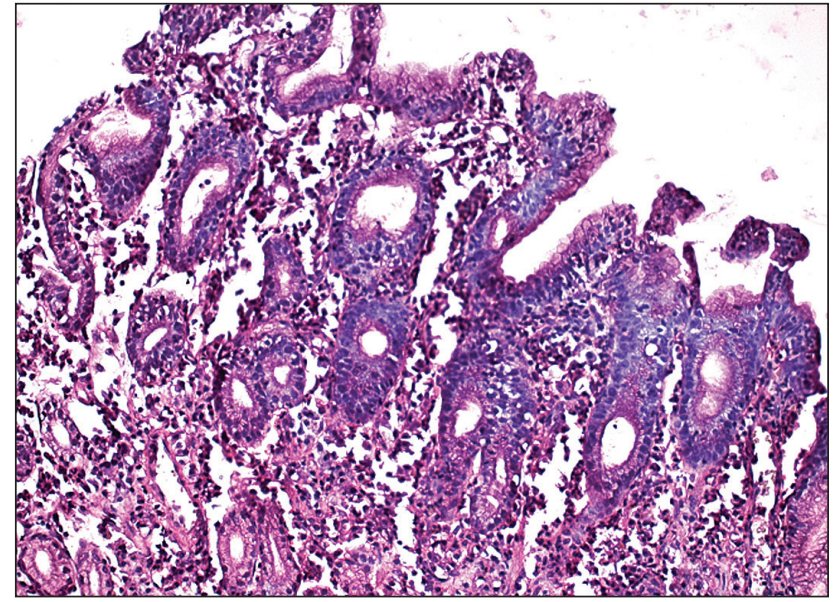

Рис. 5. Хронічний активний гастрит,

2-га стадія активності запального процесу.

Забарвлення гематоксиліном-еозином, $\times 200$

пластинку СОШ, є попередником ерозійно-виразкових дефектів.

Відомо, що присутність у складі запального інфільтрату нейтрофілів супроводжується високим рівнем продукції реактивних форм кисню (оксидативний стрес), що активують перекисне окислення ліпідів. Також оксидативний стрес (персистенція Н. pylori - персистенція інфільтрації нейтрофілами) призводить до пошкодження ДНК епітеліальних клітин генеративних зон СОШ. Наслідком цього пошкодження є клональна альтерація гена для виникнення «стартового майданчика» пухлинного росту. Тому у патогістологічному висновку доцільно виділяти наявність/відсутність інфільтрації нейтрофілами з метою інтегральної характеристики ступеня гастриту

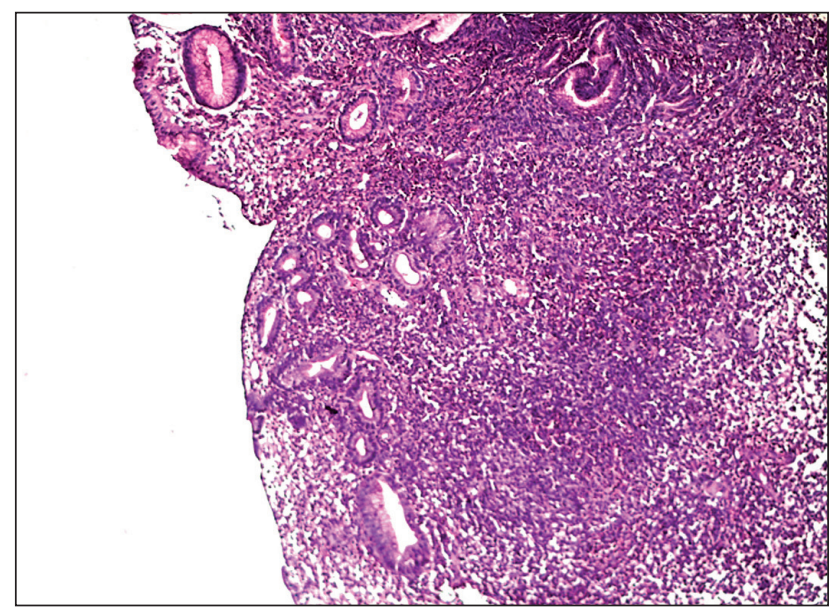

Рис. 7. Хронічний гастрит із вираженим запальним інфільтратом, що розсуває залози та імітує атрофію. Забарвлення гематоксиліном-еозином, ×100

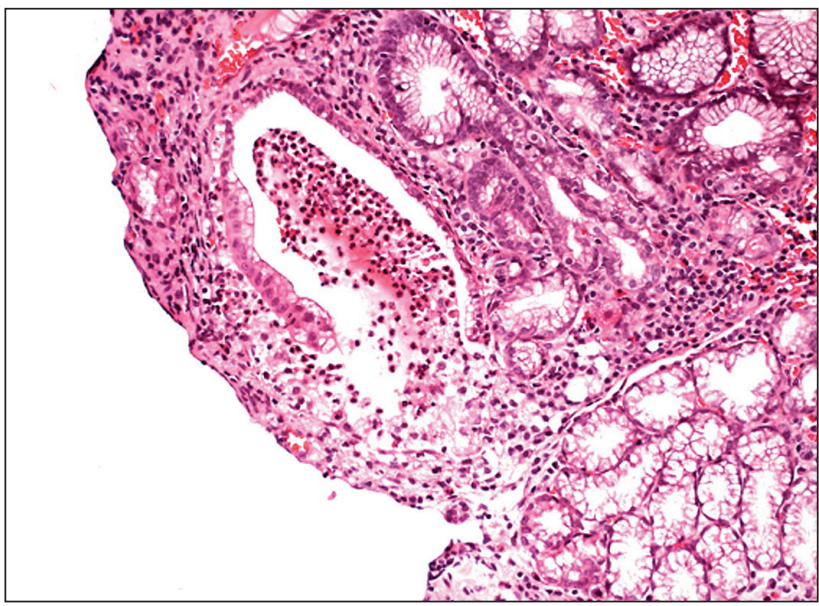

Рис. 6. Хронічний активний гастрит,

3-тя стадія активності запального процесу, «абсцес» у залозі. Забарвлення гематоксиліном-еозином, ×200.

\section{АТРОФІЯ СЛИЗОВОї ОБОЛОНКИ ШЛУНКА}

Відповідно до нової класифікації OLGA для прогнозування ризику розвитку раку шлунка враховують стадії ХГ, характеристика ж стадій визначається вираженістю атрофії СОШ.

У морфологічній діагностиці атрофії в більшості випадків є необхідною повторна біопсія. Проблема точної діагностики полягає в тому, що атрофію слизової оболонки може бути імітовано у випадках дифузної запальної інфільтрації, що розсуває залози, знижує їх кількість у полі зору, але не змінює їх абсолютної кількості (рис. 7). Визначити справжню атрофію можна лише на підставі повторного морфологічного дослідження

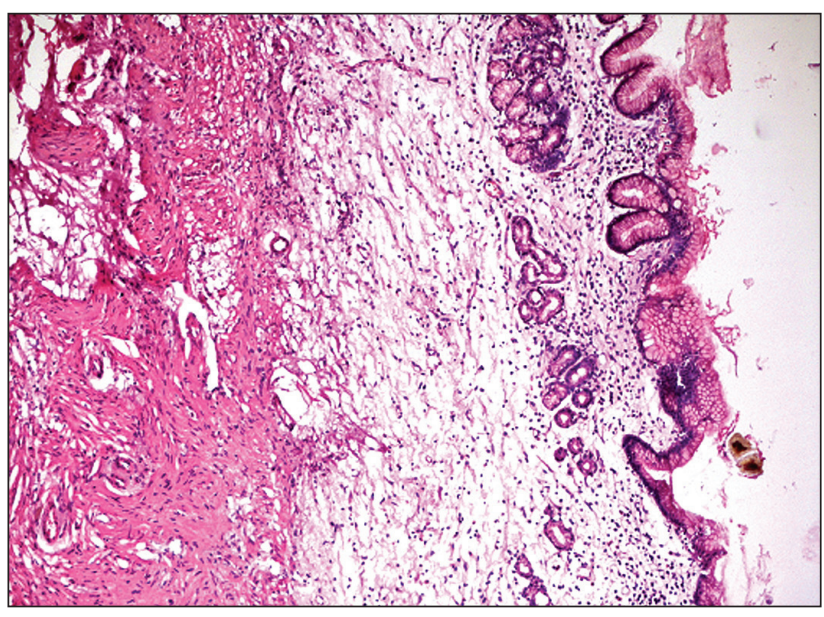

Рис. 8. Хронічний атрофічний гастрит - мала кількість залоз і значні фіброзні прошарки в слизовій оболонці. Забарвлення гематоксиліном-еозином, $\times 100$ 
після курсу протизапальної терапії. Якщо залишаються фіброзні прошарки та мала кількість залоз, то має місце справжня атрофія (рис. 8). Причому слід враховувати, що зменшення лімфоплазмоцитарної інфільтрації можна очікувати не раніше, як за декілька місяців. Повторну біопсію доцільно призначати через 6 місяців після проведення ерадикації.

До атрофії СОШ сьогодні відносять також такий iii морфологічній стан, коли кількість залоз залишається нормальною, але клітини залоз втрачають спеціалізацію, розвивається метаплазія. Отже, атрофія СОШ має два основних типа: метапластичний і неметапластичний. Неметапластичний тип характеризується втратою залоз, що супроводжується фіброзом або фібромускулярною проліферацією власної пластинки слизової оболонки. За атрофії метапластичного типу спостерігається заміщення епітелію залоз клітинами, невластивими або всьому органу (кишкова метаплазія), або його функціонально-морфологічному відділу (пілорична метаплазія у фундальному відділі).

\section{МЕТАПЛАЗІЯ СЛИЗОВОЇ ОБОЛОНКИ ШЛУНКА}

Велике значення кишкової метаплазії зумовлено іiі можливим зв’язком із раком шлунка.

Кишкова метаплазія поділяється на повну (тонкокишкову, І тип) и неповну (товстокишкову, II і III типи). Повна метаплазія характеризується появою клітин Панета та келихоподібних клітин, що продукують сіаломуцини, характерні для слизової оболонки тонкої кишки (рис. 9). Неповна кишкова метаплазія характеризується наявністю

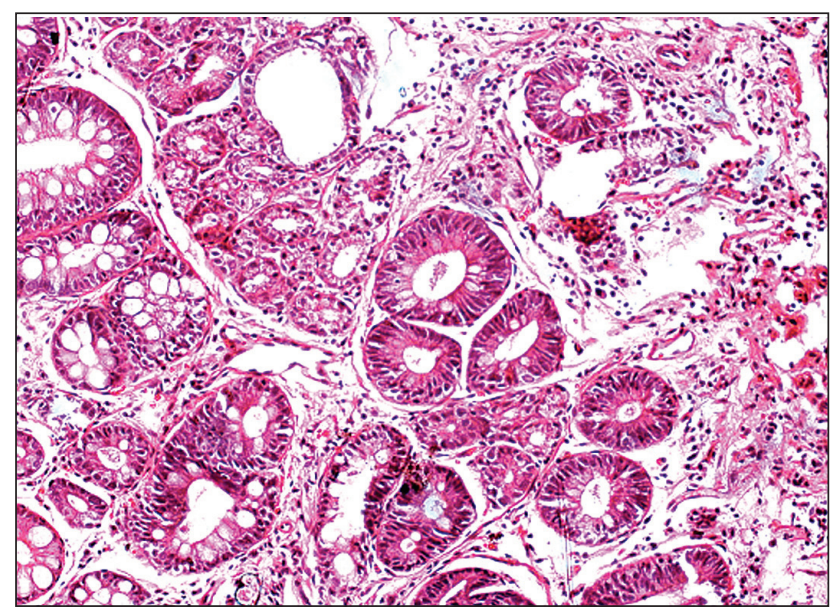

Рис. 10. Хронічний атрофічний гастрит із неповною (товстокишковою) метаплазією залоз. Забарвлення гематоксиліном-еозином, ×200.

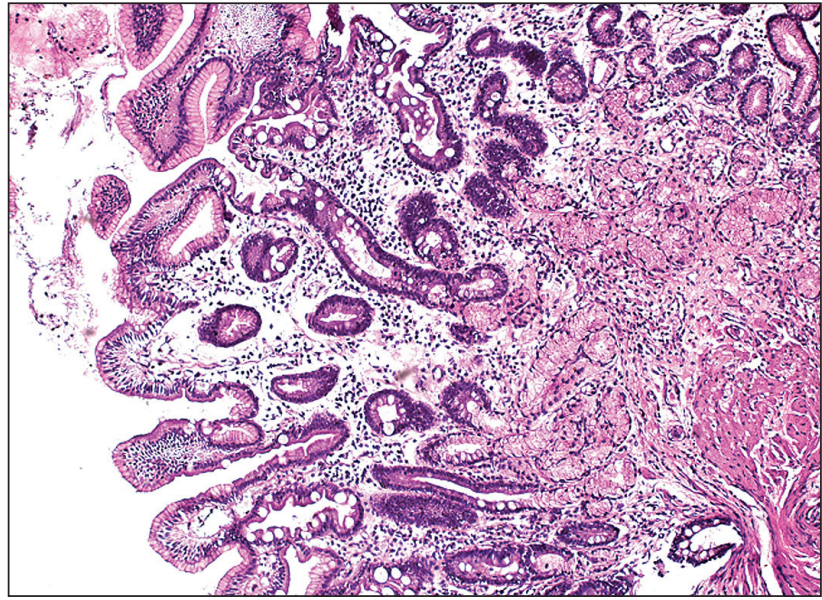

Рис. 9. Хронічний атрофічний гастрит із повною (тонкокишковою) метаплазією залоз. Забарвлення гематоксиліном-еозином, $\times 100$.

призматичного епітелію та келихоподібних клітин (рис. 10), які продукують сіаломуцини та сульфомуцини.

За кишкової метаплазії II типу клітини секретують нейтральні або кислі сіаломуцини, а за III типу - сульфомуцини. Розмежування типів кишкової метаплазії має прогностичне значення за їі Ш типу ймовірність розвитку раку шлунка $є$ в 4 рази вищою, ніж за I типу.

Часто спостерігається поєднання справжньої та метапластичної атрофії (рис. 11).

Ступінь атрофії вважають легкою, коли втрачено менше від 30\% залоз, помірною - 30-60\%, тяжкою - понад $60 \%$ залоз.

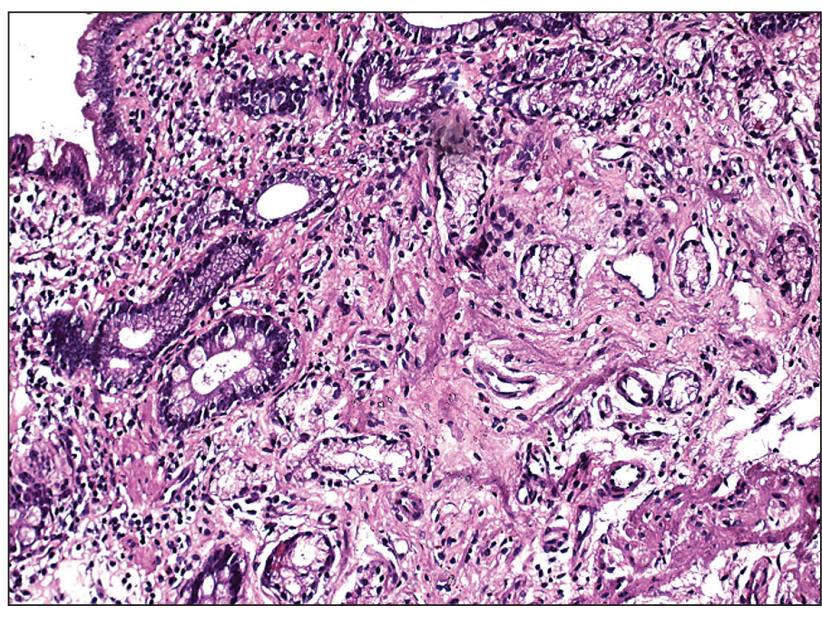

Рис. 11. Хронічний атрофічний гастрит - поєднання справжньої та метапластичної атрофії.

Забарвлення гематоксиліном-еозином, $\times 200$. 


\section{ДИСПЛАЗІЯ СЛИЗОВОЇ ОБОЛОНКИ ШЛУНКА}

Результатом тривалого існування атрофії та кишкової метаплазії може бути дисплазія - відхилення від нормальної структури клітин у напрямку неопластичного розвитку, що проявляється клітинною атипією та порушеним диференціюванням епітелію. На тлі хронічної атрофії СОШ виникають порушення клітинного оновлення з десинхронізацією фаз генерації. Підвищується мітотична активність, генеративна зона розширюється, і клітини 3 неповним визріванням зміщуються вглибину залоз і на вершини валиків. Утворюються клітини-міксти, що мають ознаки покривних і додаткових клітин. Підсилення проліферації неповністю диференційованих клітин із часом може перетворитися на дисплазію.

Дисплазією у широкому сенсі називають відхилення від нормальної структури клітин і всього тканинного комплексу в напрямку неопластичного розвитку. Експерти ВООЗ визначають дисплазію як зміни, за яких частина клітин товщі епітелію набувають ознак атипії; змін строми немає. Діагноз дисплазії підтверджується лише морфологічно. Слід зазначити, що попри широке впровадження нових діагностичних методів, зокрема електронно-мікроскопічного, імуногістохімічного, використання маркерів пренеопластичних і неопластичних змін у крові та тканинах, найефективнішим шляхом для діагностики дисплазії є грамотно виконана ендоскопічна біопсія з подальшим виготовленням гістологічних препаратів та їх оцінкою.

Згідно з рекомендаціям ВОО3, найхарактернішими ознаками дисплазії є: 1) клітинна атипія (ядерний поліморфізм, гіперхромазія, стратифікація ядер, збільшення ядерно-цитоплазматичного індексу); 2) порушення диференціювання (зникнення або зменшення кількості келихоподібних клітин і клітин Панета в метаплазованому епітелії зменшення або припинення продукції слизу клітинами епітелію); 3) порушення архітектоніки слизової оболонки (іррегулярна структура крипт, проліферація та розгалуження залоз із формуванням поверхневих і внутрішньозалозистих сосочкових структур). Отже, дисплазією вважають зміни епітелію, що передують розвитку раку.

Залежно від вираженості структурних змін відтоді як було сформульовано чітке визначення дисплазії виділяють три ії ступеня - слабкий, помірний і тяжкий. Цією класифікацією багато морфологів керуються і сьогодні.
Слабка дисплазія (1-го ступеня) в шлунку розглядається як стан, що межує з гіперплазією та справжньою дисплазію. Біологічно iï пов'язано 3 гіперпластичними та запальними процесами й 3 підсиленим клітиннимоновленням. Спостерігається подовження ямок, збільшення діаметра та гіперхроматоз ядер, збільшення ядерно-цитоплазматичного співвідношення.

За помірно вираженої дисплазії (2-го ступеня) зміни, характерні для слабкої дисплазії, стають більш вираженими. За вмістом ДНК та ультраструктурними змінами помірна дисплазія не відрізняється від слабкої. Чіткої межі у визначенні дисплазії 1-го та 2-го ступенів немає, діагностика певною мірою є суб’єктивною.

Тяжка дисплазія (3-го ступеня) характеризується клітинною атипією, гіперхроматозом ядер, анізокаріозом, збільшенням ядерно-цитоплазматичного співвідношення, псевдостратифікацією.

Дисплазія виникає як в епітелії без метаплазії, так і в метаплазованому епітелії. У більшості випадків тяжкої дисплазії вона виникає в епітелії з метаплазією.

Натомість слід зауважити, що виділення трьох ступенів дисплазії - слабкої, помірної й тяжкої - не досить вдалий підхід для клінічної оцінки цього терміну. По-перше, диспластичний епітелій складно диференціювати від епітелію гіперпластичного, регенеруючого. Для диференційної діагностики цих станів епітелію необхідно оцінювати наявність змін строми, клітинної інфільтрації, які не є характерними для дисплазії. По-друге, можливість регресії дисплазії ставить під сумнів положення про її передраковий характер.

Регресія дисплазії відбувається за дисплазій слабкого та помірного ступенів. Оцінити можливість регресії дисплазії досить складно, адже така оцінка може бути здійсненою лише після повторної біопсії, а взяти шматочки слизової оболонки саме 3 місця попередньо встановленої дисплазії навряд чи реально навіть за наявності найсучаснішої ендоскопічної апаратури.

Міжнародна група з вивчення раку шлунка 1984 року запропонувала виділяти дисплазії низького (рис. 12, 13) і високого ступенів (рис. 14, 15).

За дисплазії низького ступеня на тлі вираженого гастриту в пацієнтів віком понад 60 років рекомендується проведення повторних езофагогастроскопій із біопсію кожні 6-12 місяців. 


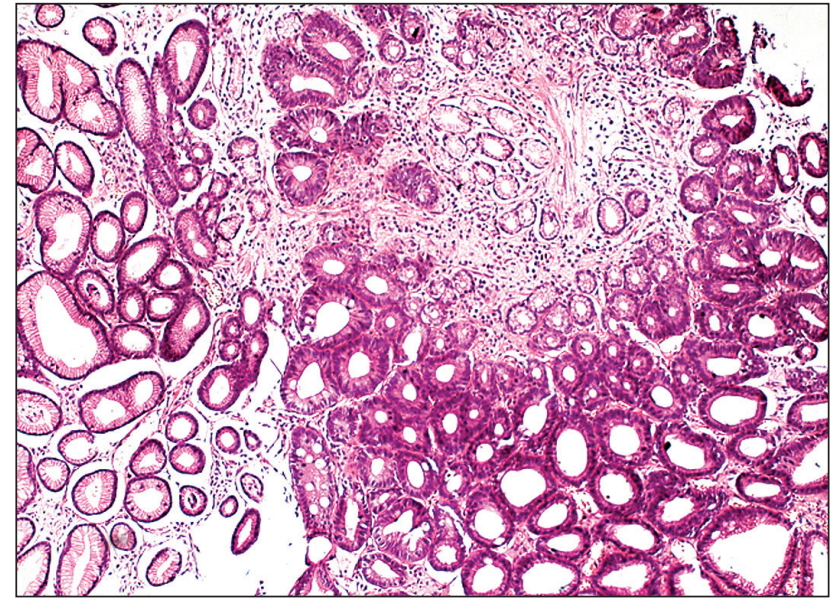

Рис. 13. Слизова оболонка шлунка - хронічний атрофічний гастрит, неповна кишкова метаплазія залоз із дисплазією низького ступеня..

Забарвлення гематоксиліном-еозином, $\times 200$.

2000 року з'явилася нова узгоджена Міжнародна (Віденська) класифікація епітеліальних неоплазій травного каналу. Вітчизняними фахівцями в галузі ендоскопії 2004 року опубліковано коментар до цієї класифікації, в якому автори пишуть, що дисплазію в класифікації визначено як неоплазію, тобто пухлину (неоплазма - клон клітин, що відрізняється від інших автономним ростом і соматичними мутаціями). Отже, вона вимагає з боку клініцистів відповідного ставлення, яке визначається стадією процесу.

За визначенням ВОО3 (2010 р.), дисплазія епітелію включає в себе пухлинну проліферацію, яка характеризується варіативною клітинною та цитоархітектурною атипією, але без переконливих ознак інвазії.

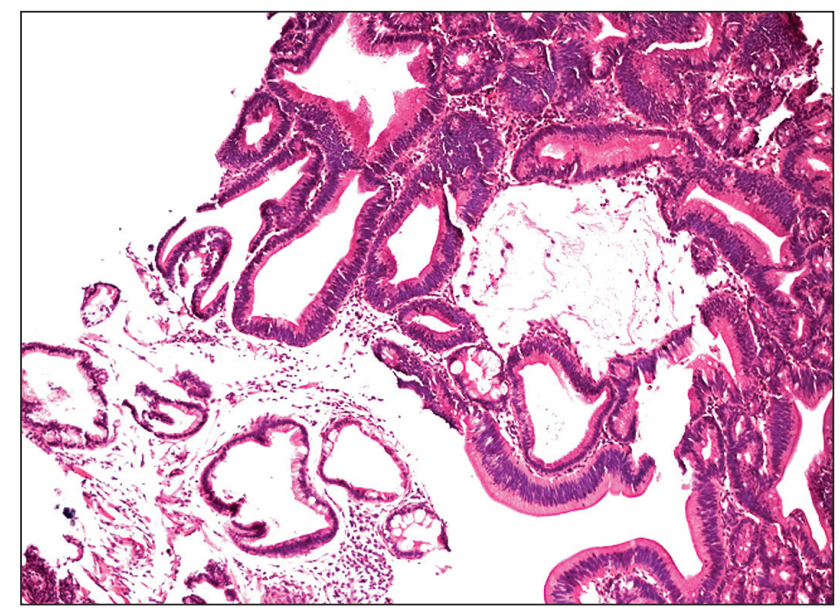

Рис. 14. Дисплазія слизової оболонки шлунка тяжкого ступеня. Забарвлення гематоксиліном-еозином, ×200.

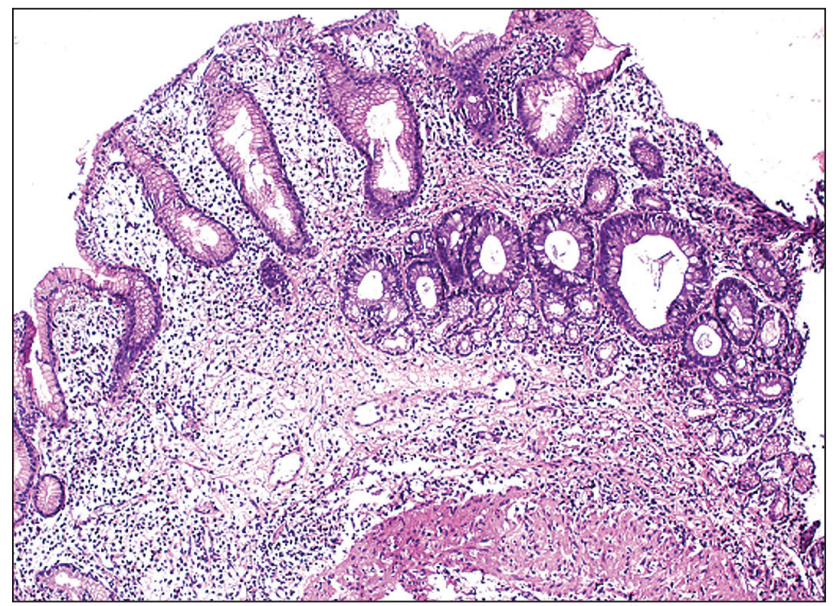

Рис. 14. Дисплазія слизової оболонки шлунка тяжкого ступеня.

Забарвлення гематоксиліном-еозином, $\times 200$

Наразі найефективнішим методом, що дозволяє відрізнити справжню дисплазію від дисрегенераторних змін, є імуногістохімічне визначення маркерів апоптозу - p53 i bcl-2, а також маркера проліферації епітеліальних клітин - Ki-67. Вважається, що порушення регуляції апоптозу внаслідок мутації р53 є однією з початкових ланок ву канцерогенезі раку шлунка, принаймні кишкового типу. Отже, можна припустити, що дисплазія, яка експресує p53, є передраком, або раком на молекулярному рівні.

За наявності у біоптаті ознак дисплазії високого ступеня рекомендується провести множинні повторні біопсії, оскільки така дисплазія частіше може свідчити не про загрозу раку, а про його наявність. Якщо навіть рак не знайдено, доцільним є

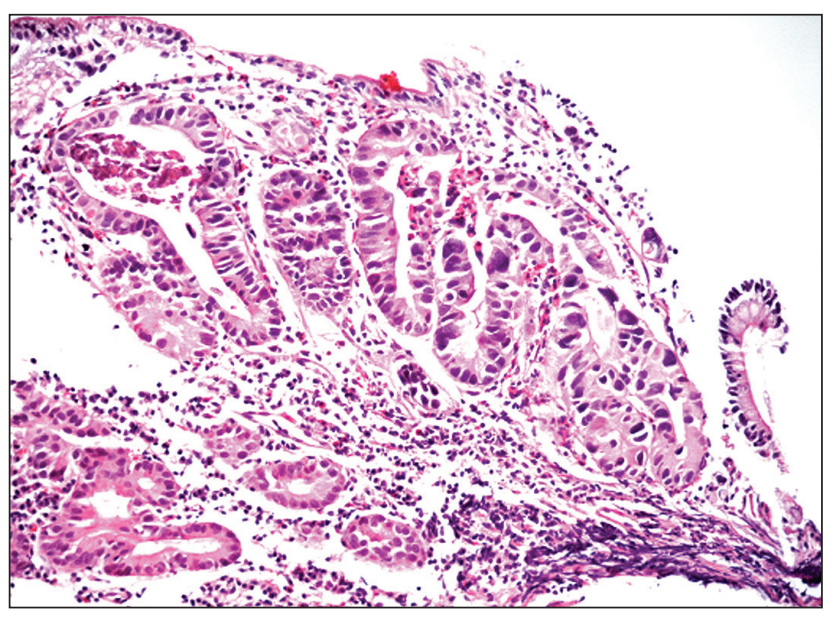

Рис. 15. Дисплазія слизової оболонки шлунка тяжкого ступеня. Забарвлення гематоксиліном-еозином, $\times 200$.

Клінічна та профілактична медицина, № 1(4)/2018 
хірургічне лікування, оскільки навіть ретельне спостереження з частими ендоскопіями та біопсіями не дає гарантії діагностики курабельного раку, адже злоякісна трансформація дисплазії високого ступеня в рак може статися раптово, і цей момент може бути пропущений у динамічному спостереженні. У таких випадках слід застосовувати ендоскопічні методи резекції або дисекції СОШ

\section{ХРОНІЧНИЙ ГАСТРИТ ЯК ПЕРЕДРАКОВИЙ СТАН}

Якщо визначати зв'язок ХГ із раком шлунка, слід розглянути деякі питання його пато- і морфогенезу. Парадигма змін СОШ, що починаються із запальної інфільтрації, включають феномен кишкової метаплазії, призводять до атрофії, дисплазії та неоплазії епітелію та мають кінцевим результатом рак шлунка кишкового типу, - отримала назву “каскаду Корреа" (за автором, який описав ці зміни 1995 року).

Разом із тим виникає питання: кишкова метаплазія, атрофія слизової оболонки шлунка, дисплазія та неоплазія - ланцюг подій, що розвиваються послідовно, чи є відносно незалежними морфологічними феноменами? Ця послідовність може належати до раку шлунка кишкового типу. За раку шлунка дифузного типу така послідовність відсутня, і він може розвиватися на тлі хронічного неатрофічного гастриту.

Виділяють два шляхи канцерогенезу. Для першого характерним є первинне пошкодження механізмів проліферації та диференціації. Цей процес тривалий, початок його - хронічний активний гастрит, який через кишкову метаплазію та дисплазію завершується розвитком раку шлунка киш-

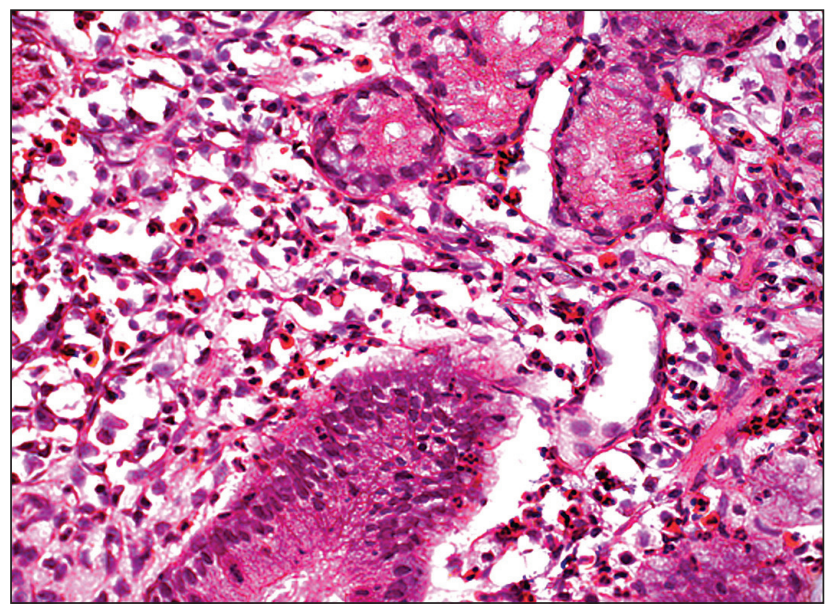

Рис. 16. Еозинофільний гастрит.

Забарвлення гематоксиліном-еозином, $\times 400$ кового типу. Другий шлях канцерогенезу характеризується порушенням експресії або мутацією генів, відповідальних за синтез білків базальної мембрани. Процес розгортається досить швидко і призводить до формування раку з неопластичного шийкового епітелію. Ініціює обидва представлені шляхи канцерогенезу хелікобактерний активний ХГ, що втягує в процес генеративну зону епітелію шлунка.

Міжнародне агентство з вивчення раку ВОО3 визнало достатніми наявні докази канцерогенності інфекції Н. Pylori, і рекомендує за цим критерієм віднести іiі до канцерогенів I групи. Для переривання патологічного каскаду подій, що пов'язують ХГ і рак шлунка, необхідно видалити один із чинників ризику, тобто провести ерадикацію H. pylori. Отже, за хронічного атрофічного гастриту ерадикація H. pylori має принципове значення як найбільш обгрунтований захід для профілактики раку шлунка.

\section{ІНШ ФОРМИ НЕХЕЛІКОБАКТЕРНОГО ГАСТРИТУ}

Основним гістологічним проявом лімфоцитарного гастриту є наявність численних зрілих лімфоцитів у поверхневих шарах епітелію. Етіологію та взаємозв'язок із Helicobacter-асоційованим гастритом не встановлено.

Еозинофільний гастрит характеризується набряком слизової та наявністю численних еозинофілів у запальному інфільтраті (рис. 16). Припускають, що еозинофільний гастрит - це алергічна відповідь на харчовий антиген, до якого хворий сенсибілізований.

Гранульоматозний гастрит - рідкісна форма гастриту, коли формуються епітеліоїдноклітинні гранульоми. Ці гранульоми можуть бути проявом хвороби Крона або саркоїдозу, проте в окремих випадках він буває криптогенним

\section{АВТОІМУННИЙ ХРОНІЧНИЙ ГАСТРИТ}

У хворих із ХГ цього типу в крові виявляються антитіла проти парієтальних клітин шлункових залоз і проти рецепторів до зовнішнього чинника Кастла. У цих хворих спостерігається гіпохлоргідрия аж до ахлоргідрії та В12-дефіцитна анемія. Макроцитарна анемія, що асоціюється 3 автоімунним гастритом, називається «перніціозною анемією». Найчастіше уражається тіло шлунка (фундальний гастрит): пошкоджуються спеціалізовані парієтальні (обкладальні) клітини (атрофія залоз) і заміщується власна пластинка слизової 
оболонки фіброзною тканиною, відбувається інфільтрація лімфоцитами та плазматичними клітинами

\section{ХІМІЧНИЙ (РЕФЛЮКС) ГАСТРИТ}

За регургітації жовчі та лужного дуоденального вмісту в шлунок відбувається посилена десквамація епітелію, компенсаторна гіперплазія проліферуючих клітин на дні шлункових ямок, вазодилятація та набряк lamina propria, що і є проявом рефлюксгастриту. Рефлюкс-гастрит найчастіше спостерігається: а) у хворих після операцій, що пошкоджують пілорус; б) як результат порушення моторики кишечнику га тлі жовчнокам'яної хвороби та після холецистектомії; в) у хворих із порушенням антродуоденальної моторики, яке може бути як первинним, так і вторинним внаслідок патологічної відпо- віді на гормони, такі як холецистокінін і секретин, що в нормі збільшують тонус пілоруса за умов підвищення кислотності в 12-палій кишці. За тривалого існування рефлюкс-гастриту можливо утворення виразок.

\section{ВИСНОВКИ}

1. Морфологічний метод діагностики є основним у встановленні діагнозу «хронічний гастрит».

2. Використання сучасної класифікації хронічного гастриту OLGA 3 елементами попередніх класифікацій дозволяє досягти максимально інформативної діагностики.

3. Морфологічна оцінка стадії та ступеня хронічного гастриту визначає індивідуальний прогноз і тактику ведення пацієнта, яка певною мірою забезпечує профілактику виникнення виразки та раку шлунка.

\section{ЛITEPATУPA}

Ben Slama S., Ben Ghachem D., Dhaoui A., Jomni M.T., Dougui M.H., Bellil K. Helicobacter pylori gastritis: assessment of OLGA and OLGIM staging systems. Pan Afr. Med. J. 2016. 4. P.23:28. doi: 10.11604/ pamj.2016.23.28.8839.

2. Capelle L..G, de Vries A.C., Haringsma J., Ter Borg F., de Vries R.A., Bruno M.J., van Dekken H., Meijer J., van Grieken N.C., Kuipers E.J. The staging of gastritis with the OLGA system by using intestinal metaplasia as an accurate alternative for atrophic gastritis. Gastrointest. Endosc. 2010. 71. P.1150-1158. doi: 10.1016/j. gie.2009.12.029.

3. Dinis-Ribeiro M., Areia M., de Vries A.C., Marcos-Pinto R., Monteiro-Soares M., O'Connor A., Pereira C., Pimentel-Nunes P., Correia R, Ensari A. Management of precancerous conditions and lesions in the stomach (MAPS): guideline from the European Society of Gastrointestinal Endoscopy (ESGE), European Helicobacter Study Group (EHSG), European Society of Pathology (ESP), and the Sociedade Portuguesa de Endoscopia Digestiva (SPED) Endoscopy. 2012. 44 P.74-94. doi: 10.1055/s-0031-1291491.

4. Isajevs S., Liepniece-Karele I., Janciauskas D., Moisejevs G., Putnins V., Funka K., Kikuste I., Vanags A., Tolmanis I., Leja M. Gastritis staging: interobserver agreement by applying OLGA and OLGIM systems. Virchows Arch. 2014. 464. P. 403-407. doi: 10.1007/s00428-014-1544-3.

5. Marcos-Pinto R., Carneiro F., Dinis-Ribeiro M., Wen X., Lopes C., Figueiredo C., Machado J.C., Ferreira R.M., Reis C.A., Ferreira J. First-degree relatives of patients with early-onset gastric carcinoma show even at young ages a high prevalence of advanced OLGA/OLGIM stages and dysplasia. Aliment. Pharmacol. Ther. 2012. 35. P.1451-1459. doi.org/10.1111/j.1365-2036.2012.05111.

6. Nam J.H., Choi I.J., Kook M.C., Lee J.Y., Cho S.J., Nam S.Y., Kim C.G. OLGA and OLGIM stage distribution according to age and Helicobacter pylori status in the Korean population. Helicobacter. 2014.19. P.81-89. doi. org/10.1111/hel.12112.
7. Quach D.T., Le H.M., Nguyen O.T, Nguyen T.S., Uemura $\mathrm{N}$. The severity of endoscopic gastric atrophy could help to predict Operative Link on Gastritis Assessment gastritis stage. J. Gastroenterol. Hepatol. 2011. 26. P. 281-285. doi: 10.1111/j.1440-1746.2010.06474.x.

8. Quach D.T., Le H.M., Hiyama T., Nguyen O.T., Nguyen T.S., Uemura N. Relationship between endoscopic and histologic gastric atrophy and intestinal metaplasia. Helicobacter. 2013. 18. P.151-157. doi: 10.1111/ hel.12027.

9. Rugge M., Correa P., Di Mario F., El-Omar E., Fiocca R., Geboes K., Genta R.M., Graham D.Y., Hattori T., Malfertheiner P. OLGA staging for gastritis: a tutorial. Dig. Liver Dis. 2008. 40. P.650-658. doi: $10.1177 / 1066896907307238$.

10. Rugge M., de Boni M., Pennelli G., de Bona M., Giacomelli L., Fassan M., Basso D., Plebani M., Graham D.Y. Gastritis OLGA-staging and gastric cancer risk: a twelve-year clinico-pathological follow-up study. Aliment. Pharmacol Ther. 2010. 31. P.1104-1111. doi: 10.1111/j.1365-2036.2010.04277.

11. Rugge M., Fassan M., Pizzi M., Farinati F., Sturniolo G.C., Plebani M., Graham D.Y. Operative link for gastritis assessment vs operative link on intestinal metaplasia assessment. World J. Gastroenterol. 2011. 17. P. 45964601. doi: 10.1016/j.humpath.2010.12.017.

12. Rugge M., Pennelli G., Pilozzi E., Fassan M., Ingravallo G., Russo V.M., Di Mario F. Gruppo Italiano Patologi Apparato Digerente (GIPAD); Societ Italiana di Anatomia Patologica e Citopatologia Diagnostica/ International Academy of Pathology, Italian division (SIAPEC/IAP). Gastritis: the histology report. Dig. Liver Dis. 2011. 43(4). S. 373-84. doi: $10.1016 / \mathrm{S} 1590$ 8658(11)60593-8.

13. Saf C., Gulcan E.M., Ozkan F. Assessment of p21, p53 expression, and $\mathrm{Ki}-67$ proliferative activities in the gastric mucosa of children with Helicobacter pylori gastritis. Eur. J. Gastroenterol. Hepatol. 2015. 27(2). P.155-161. doi: 10.1097/MEG.0000000000000246. 
14. Yue H., Shan L., Bin L. The significance of OLGA and OLGIM staging systems in the risk assessment of gastric cancer: a systematic review and meta-analysis. Gastric Cancer. 2018. 21(4). P. 579-587. doi: 10.1007/s10120018-0812-3.
15. Zhou Y., Li H.Y., Zhang J.J., Chen X.Y., Ge Z.Z., Li X.B. Operative link on gastritis assessment stage is an appropriate predictor of early gastric cancer. World $\mathrm{J}$. Gastroenterol. 2016. 22(13). P. 3670-8. doi: 10.3748/wjg. v22.i13.3670.

\section{REFERENCES}

1. Ben Slama S., Ben Ghachem D., Dhaoui A., Jomni M.T., Dougui M.H., Bellil K. (2016). Helicobacter pylori gastritis: assessment of OLGA and OLGIM staging systems. Pan Afr. Med. J., 4, 23-28. doi: 10.11604/ pamj.2016.23.28.8839.

2. Capelle L..G, de Vries A.C., Haringsma J., Ter Borg F., de Vries R.A., Bruno M.J., van Dekken H., Meijer J., van Grieken N.C., Kuipers E.J. (2010). The staging of gastritis with the OLGA system by using intestinal metaplasia as an accurate alternative for atrophic gastritis. Gastrointest. Endosc., 71, 1150-1158. doi: 10.1016/j.gie.2009.12.029.

3. Dinis-Ribeiro M., Areia M., de Vries A.C., MarcosPinto R., Monteiro-Soares M., O'Connor A., Pereira C., Pimentel-Nunes P., Correia R, Ensari A. (2012). Management of precancerous conditions and lesions in the stomach (MAPS): guideline from the European Society of Gastrointestinal Endoscopy (ESGE), European Helicobacter Study Group (EHSG), European Society of Pathology (ESP), and the Sociedade Portuguesa de Endoscopia Digestiva (SPED) Endoscopy, 44, 74-94. doi: 10.1055/s-0031-1291491.

4. Isajevs S., Liepniece-Karele I., Janciauskas D., Moisejevs G., Putnins V., Funka K., Kikuste I., Vanags A., Tolmanis I., Leja M. (2014). Gastritis staging: interobserver agreement by applying OLGA and OLGIM systems. Virchows Arch., 464, 403-407. doi: 10.1007/s00428014-1544-3.

5. Marcos-Pinto R., Carneiro F., Dinis-Ribeiro M., Wen X., Lopes C., Figueiredo C., Machado J.C., Ferreira R.M., Reis C.A., Ferreira J. (2012). First-degree relatives of patients with early-onset gastric carcinoma show even at young ages a high prevalence of advanced OLGA/OLGIM stages and dysplasia. Aliment. Pharmacol. Ther., 35, 1451-1459. doi.org/10.1111/j.1365-2036.2012.05111.

6. Nam J.H., Choi I.J., Kook M.C., Lee J.Y., Cho S.J., Nam S.Y., Kim C.G. (2014). OLGA and OLGIM stage distribution according to age and Helicobacter pylori status in the Korean population. Helicobacter, 19, 81-89. doi.org/10.1111/hel.12112.

7. Quach D.T., Le H.M., Nguyen O.T, Nguyen T.S., Uemura N. (2011). The severity of endoscopic gastric atrophy could help to predict Operative Link on Gastritis Assessment gastritis stage. J. Gastroenterol. Hepatol., 26, 281-285. doi: 10.1111/j.1440-1746.2010.06474.x.
8. Quach D.T., Le H.M., Hiyama T., Nguyen O.T., Nguyen T.S., Uemura N. (2013). Relationship between endoscopic and histologic gastric atrophy and intestinal metaplasia. Helicobacter, 18, 151-157. doi: 10.1111/hel.12027.

9. Rugge M., Correa P., Di Mario F., El-Omar E., Fiocca R., Geboes K., Genta R.M., Graham D.Y., Hattori T., Malfertheiner P. (2008). OLGA staging for gastritis: a tutorial. Dig. Liver Dis., 40, 650-658. doi: 10.1177/1066896907307238.

10. Rugge M., de Boni M., Pennelli G., de Bona M., Giacomelli L., Fassan M., Basso D., Plebani M., Graham D.Y. (2010). Gastritis OLGA-staging and gastric cancer risk: a twelve-year clinico-pathological follow-up study. Aliment. Pharmacol Ther., 31, 11041111. doi: 10.1111/j.1365-2036.2010.04277.

11. Rugge M., Fassan M., Pizzi M., Farinati F., Sturniolo G.C., Plebani M., Graham D.Y. (2011). Operative link for gastritis assessment vs operative link on intestinal metaplasia assessment. World J. Gastroenterol., 17, 4596-4601. doi: 10.1016/j.humpath.2010.12.017.

12. Rugge M., Pennelli G., Pilozzi E., Fassan M., Ingravallo G., Russo V.M., Di Mario F. (2011). Gruppo Italiano Patologi Apparato Digerente (GIPAD); Società Italiana di Anatomia Patologica e Citopatologia Diagnostica/ International Academy of Pathology, Italian division (SIAPEC/IAP). Gastritis: the histology report. Dig. Liver Dis., 43(4), 373-84. doi: 10.1016/S1590-8658(11)60593-8.

13. Saf C., Gulcan E.M., Ozkan F. Assessment of p21, p53 expression, and $\mathrm{Ki}-67$ proliferative activities in the gastric mucosa of children with Helicobacter pylori gastritis. Eur. J. Gastroenterol. Hepatol. 2015. 27(2). P.155-161. doi: 10.1097/ MEG.0000000000000246.

14. Yue H, Shan L, Bin L. (2018) The significance of OLGA and OLGIM staging systems in the risk assessment of gastric cancer: a systematic review and meta-analysis. Gastric Cancer.,21(4), 579-587. doi: 10.1007/s10120018-0812-3.

15. Zhou Y., Li H.Y., Zhang J.J., Chen X.Y., Ge Z.Z., Li X.B. (2016). Operative link on gastritis assessment stage is an appropriate predictor of early gastric cancer. World J. Gastroenterol., 22(13), 3670-8. doi: 10.3748/wjg.v22. i13.3670. 


\section{Резюме}

\section{ХРОНИЧЕСКИЙ ГАСТРИТ: СОВРЕМЕННЫЕ КЛИНИКО-МОРФОЛОГИЧЕСКИЕ ПРЕДСТАВЛЕНИЯ (Лекция) \\ Е.Г. Курик, М.Ю. Коломоец}

Государственное научное учреждение «Научно-практический центр профилактической и клинической медицины» Государственного управления делами, Киев

В лекции представлены современные клинико-морфологические классификации хронического гастрита. Выделен основной этиологический фактор хронического гастрита - инфекция H. pylori. Аано определение понятия атрофии, отмечено, что атрофия может быть имитированной за счет воспалительного инфильтрата. Рассмотрены типы атрофии - метапластический и неметапластический. Охарактеризованы типы метаплазии слизистой оболочки желудка - полная (тонкокишечная) и неполная (толстокишечная); отмечено, что неполная метаплазия является предраковым состоянием. Аана характеристика дисплазий слизистой оболочки желудка. Рассмотрены два пути канцерогенеза рака желудка, отмечено, что Н. pylori относится к канцерогенам I группы. Рассмотрены другие формы нехеликобактерного хронического гастрита.

Ключевые слова: хронический гастрит, инфекция Н. pylori, атрофия, метаплазия, дисплазия.

\section{Summary}

\section{CHRONIC GASTRITIS}

\section{O.G. Kuryk, M.Yu. Kolomoyets}

State Scientific Institution "Scientific-Practical Centre of Preventive and Clinical Medicine" State Administration of Affairs Kyiv, Ukraine

The modern clinico-morphological classification of chronic gastritis was given. H. pylori as a main ethiological factor of chronic gastritis was determined. The determination of atrophy of gastric mucosa was given, and we accented, that atrophy may be imitating by inflamate infiltrate. Two types of atrophy metaplastic and non-metaplastic was examined. The types of metaplasia of gastric mucosa - full (intestinal) and non-full (colon) and the role of colon metaplasia in genesis of gastric cancer was given. The characteristic of dysplasia, its criteria and difficulty of diagnostic was given. Two ways of cancerogenesis of gastric cancer with H. pylori as cancerogene of I group was examined. Some another forms of non-helicobacter chronic gastritis was showen.

Keywords: chronic gastritis, H. pylori infection, atrophy, metaplasia, dysplasia.

Інформація про авторів знаходиться в редакції.

Дата надходження до редакції 01.08.2018 р. 